\title{
Changing Face of Sea Piracy in the Eastern Indian Ocean Region: Examining India's Role in Maritime Cooperation
}

\author{
Amrita Dey
}

Abstract

\begin{abstract}
There is hardly any dispute that the Eastern Indian Ocean like its historical past is once again emerging into a 'cosmopolitan' maritime arena underpinned by long stretches of peaceful exchange of commodities, energy and other maritime accessories. It has witnessed a new constellation of 'inward-looking' regional powers with a 'bazaar nexus' (for mercantile goods and energy supply) with Asian and nonAsian powers. Economically, small and middle powers of this region do share and accommodate all to draw the benefits of a highly globalised 'closely-knit' mercantile system. Problems relating to trade hazards'maritime mugging,' 'sea piracy,' 'illegal transfer of arms and ammunition, maritime terrorism, has already been addressed adequately by the collective effort of member nations under the aegis of ASEAN. This goodwill effort in the maritime zone awaits response from the cultural domain as well, which still lacks its frequency and luster of the glorious past. Although loads have been talked about, there has been little in action. The present paper is an attempt to study the community building efforts of ASEAN in connivance with emerging powers like India and China; and efforts at building up an Indian Ocean community as it existed in its past-sans feuds, sans fight-but unhindered exchange of culture and trade.
\end{abstract}

Keywords: Eastern Indian Ocean, Sea Piracy, Terrorism, India, ASEAN, Maritime Cooperation 


\section{Introduction}

From 'simple adventurers' to 'commercial merchants' and later 'crude explorers' groping for new pathways to fortune, the Eastern Indian Ocean centered upon the Bay of Bengal and stretching down to the Malacca Straits, the South China Sea and beyond has represented a unique 'integrated world' alluring merchants, mariners, soldiers and poets for time immemorial.

Initially, merchants from South and Southeast Asia carried cargos from the 'Spice Island' to markets around the Bay of Bengal to entrepots in South India and Sri Lanka. These were later trans-shipped in Arab and Persian craft to ports in Persian Gulf, Arabia and the Red Sea. With commodities also came cultural and religious influences. What started as a 'well integrated' 'interregional' political, economic and cultural activity, gradually gave way to 'rampant vandalism' and 'forced incursions' unleashed by the Europeans [more so by coming of the British in the $18^{\text {th }}$ century] that literally crumbled \{but never stopped the commercial activities across this Ocean.

The sudden 'gush' of colonialism put the Ocean on a back seat and brought human activity to the forefront. Gory fights ensued between the 'indigenous people' and their colonial masters who successfully tore apart the entire Indian Ocean Region into separate regional entities - the Middle East, South and Southeast Asia.

The Europeans \{mostly the British\} stripped this Ocean off its unified cultural and religious identity. Although economic activity still exist centering the nodal junctures of this part of the Ocean - the Malacca Straits, the Sunda, Lombok Straits and the South China Sea, it has been juxtaposed with new complexities of the present era.

The present study attempts to examine the incidence of sea piracy along the Malacca Straits that has drastically come down to only two attacks by the first quarter of 2008 . This success has been largely attributed to a) constant naval patrolling by the littorals - straddling the Straits; b) Coordinated commitments of extra-regional powers to arrest this menace; c) ASEAN's success as a full-fledged legal entity with expanding room for 'constructive engagement' and its commitment towards building up an ASEAN community and a common market by 2015; d) Increased involvement of India, as New Delhi's 'clean image' has given her a calling role to address the incidence and growing brutality of sea piracy, maritime terrorism and gun running in this area. So, after 50 years of independence of most of the countries along the Eastern Indian Ocean, we find a renewed attempt at forming an Eastern Indian Ocean community with all its past attributes of an economic, political and amateur cultural entity. It's only a matter of time to see this goodwill gesture spread across the entire Indian Ocean region from the Malacca Straits to the Persian Gulf. 


\section{Sea Piracy \& Maritime Terrorism Along the Malacca Straits}

The narrow Malacca Straits is one of the world's busiest sea-lane with over 200 vessels transiting daily. It is also one of the crucial energy supply lines of economicgiants like China, Japan and India. Everyday it handles over 10.3 million barrels of oil. It is estimated that the number of tankers transiting this sea-lane will increase to 59 per day in 2010 from 45 in 2000. The LPG tanker traffic is expected to increase to seven per day in 2010 from 5 in 2000 and the daily LNG tanker traffic is expected to rise to 12 per day from 8 in 2000. Any terrorist attack on these merchant vessels or oil tanker can prove disastrous for world trade, besides a) hampering the safety and lives of the citizens of various flagged states and b) trigger a major environmental disaster. One scholar had - rightly pointed out that "if terrorists were determined to devastate world trade, it would be hard to find a better target than the Malacca Straits where about 50,000 vessels carrying roughly a quarter of the world's maritime trade pass through every year". 1

\section{The Malacca Straits}

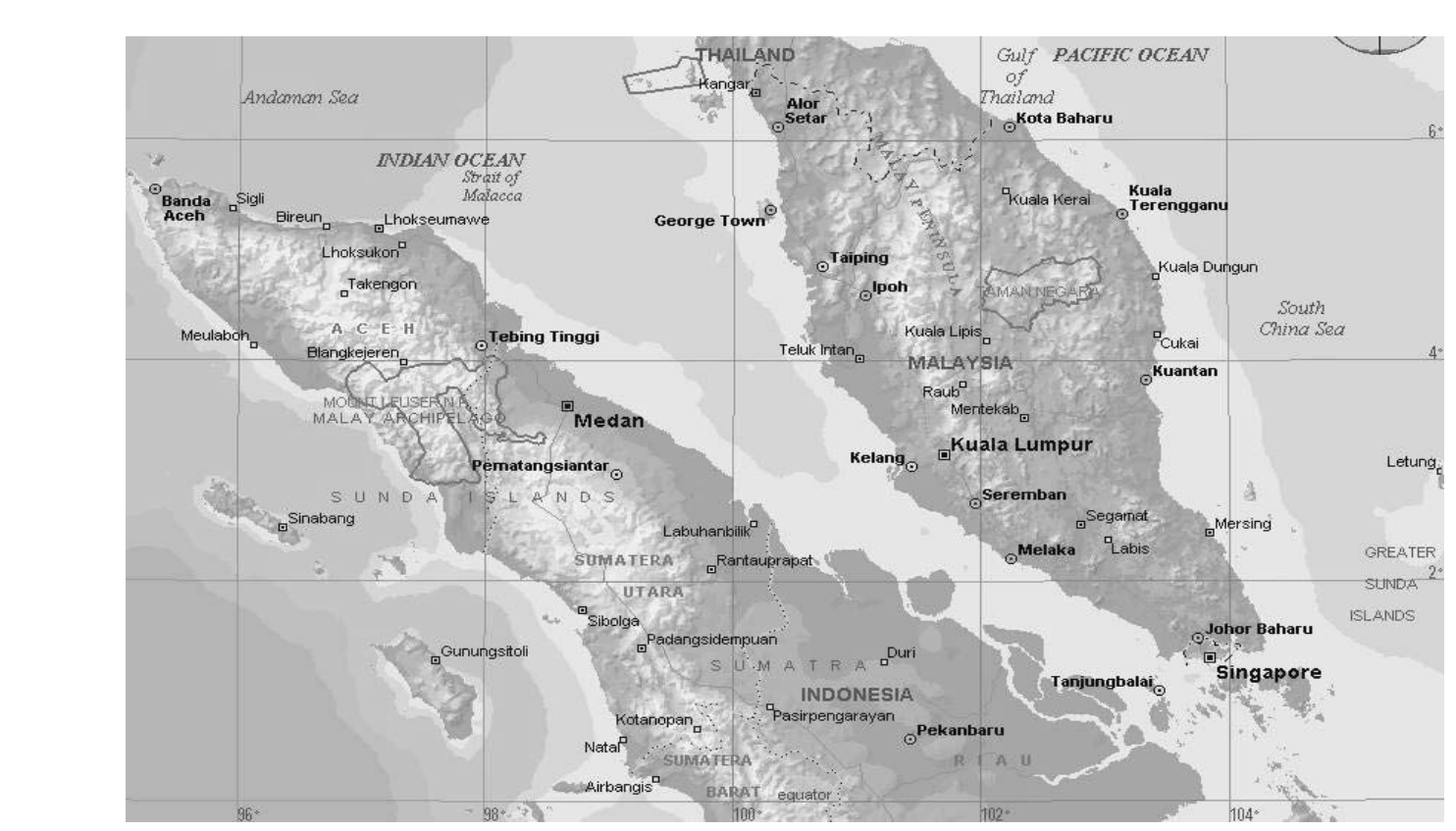

Since 1991 the International Maritime Bureau (IMB) identified the Southeast Asian waters as most vulnerable to piracy attacks accounting for $57 \%$ of the actual and attempted attacks reported globally. In the first six months of 2002, of the 171 incidents reported worldwide, the highest 44 came from Indonesia itself. The attacks vary from stealing valuables from the merchant vessel crew to seizing a ship's entire cargo or the entire ship itself. Three types of piracy have been underpinned by scholars so far; 
a) Habor and anchorage theft-The International Maritime Bureau (IMB) defines these types of assault as low-level armed robbery - an opportunist attack on a ship mounted close to land by small high-speed craft crewed by 'maritime muggers' armed with knives. Their targets are usually cash and portable, high value personal items with an average theft between $\$ 5,000$ and $\$ 15,000$.

b) Ransacking and robbing of vessels on the high seas or in territorial waters. The IMB defines these types of assault as medium-level armed assault and robbery- violent attacks of robbery involving serious injury or murder by well-organised gangs usually heavily armed and working from a 'mother ship'.

- c) Hijacking of vessels to convert them for the purpose of illegal trading-the so-called 'phantom ship phenomenon'. This type of piracy involves methods in which vessels are first seized; their cargoes are off-loaded into lighters at sea. The ships are then fraudulently re-registered, the cargo is never delivered to its intended destination, but transferred to another vessel or taken to an alternate port where it is sold to prearranged buyers. The IMB defines this type of assault as a major criminal hijack-well resourced and planned international criminal activity using a large gang of highly trained men including terrorist groups active in the area. The hijacking of Alondra Rainbow in 1999 is a classic example of the involvement of organized crime in the hijacking of ships. ${ }^{2}$

While sea piracy has been endemic to this region for hundred of years, the significance of post Cold War piracy lies in its frequency and in growing brutality of the crime. According to the former director of IMB, Captain Mukundan, "the incidents of hijacking have increased dramatically since 2000," and these are serious and violent attacks committed by organized criminal syndicates. "Crew members are often abducted or injured and both the ship and cargo worth millions of dollars are often stolen," Mukundan said. Out of the 72 casualties reported in 2000, 57 deaths were due to attacks by terrorists rather than pirates, as 17 sailors died on the USS Cole and 40 deaths were due to a bomb explosion abode a ferry in the Philippines. The figures also showed an increased use of firearms and guns, up from 51 in 2000 to 73 in 2001 while the use of knives fell from 132 to $105 .{ }^{3}$ On 27 March 2003, The New York Times reported attacks on several chemical tankers in the Malacca Straits by assailants with automatic weapons. On 25 February 2003 and 18 March of the same year two ships - the Suhaila and the Oriental Salvia were sprayed with AK-47 rifles in the broad daylight along the Malacca Straits. On 26 March 2003, the Dewi Madrim was silently boarded at night, commandeered for an hour and looted. While some attributed the attacks to terrorists it was later discovered that the perpetrators were only after equipment and other valuables. In February 2004, the Abu Sayyaf Group (ASG) attacked a passenger ferry Supertanker 14 in the Manila Bay killing 116 people, making it the worst act of maritime terrorism of recent times. ${ }^{4}$ These incidents along with the suicide mission on three speedboats targeting the Al-Bakr and Al-Amiq oil terminal in Iraq (April 2004) called upon the international community to place the term 'maritime terrorism' in the strategic vocabulary of maritime security. The Council for Security Cooperation in Asia-Pacific defined maritime terrorism 'as an 
unlawful act of violence at sea with an intention for political or destructive end but not those associated with war declared under the laws of war'.5 On February 2007 the Indian Coastguard intercepted an LTTE boat off the Tamil Nadu coast carrying a cargo of suicide jackets, plastic explosive, AK-47 rifles and live ammunition bound for Southeast Asia.

\section{Problems in Combating Maritime Crime}

While poverty, unemployment and gross deprivation maybe logical explanations behind such high incidence of piracy in the region (this may not be a sufficient explanation for - terrorist groups like Al-Qaeda and Jemaah Islamiya where their recruits are selected from middle-class backgrounds), most of the unilateral efforts of the littoral states to combat the menace has been incapacitated by weak law and order, corruption, lax immigration controls, political subordination of large segments of the population and pressure of separatist/terrorist groups threatening disintegration of the core ASEAN countries. Besides, the problem of state jurisdiction has further complicated the problem of sea - piracy and maritime terrorism in this area. In most cases the state concerned has to call off the chase because of the suspect vessels easy access to a neighboring national boundary where no agreement of 'passe comitatus' has been signed. The May 1992 Royal Malaysian Police marine chase against a stolen trawler preying on other vessels substantially illustrates this fact. The Malaysians were forced to call off the chase when the suspect vessel entered the Philippines water. As no agreement of passé comitatus was signed between Manila and Kuala Lumpur it worked to the advantage of the fleeing - trawler. To add on, most acts of 'sea robbery' in Southeast Asia takes place in the territorial waters that are not covered by Article 15 of the 1958 Geneva Conventionwhich defines piracy as an act that in some ways endanger the safe navigation of a ship on the high seas. ${ }^{6}$ Even the naval resources of the region's coastal states suffer acute scarcity. According to the IMB, Thailand possesses only 60 coastal patrol and combatant craft, Indonesia 57, the Philippines 54, Malaysia 37 and Singapore 19- these being insufficient to cover their respective territorial waters.

\section{Efforts at Combating Maritime Crime}

Post 11 September/2001, most of the countries having woken up to the reality centering the increasing vulnerability of the SLOCs (reports confirmed that the Al Qaeda owned some 20 terror ships in the Asia Pacific region) came up with some 'quick response' to arrest the problem. The Royal Malaysian Navy (RMN) for instance established the Malaysian Maritime Enforcement Agency (MMEA) in November 2005. This coast-guard type organization providing sea-going constabulary services funded with an initial budget of $\$ 75$ million is mainly used to acquire radar and patrol boats to coordinate naval and police operations to deter terrorism, piracy and illegal immigration, environmental and pollution control and aid search and rescue efforts. 
In July 2003, the Indonesian Navy (TNI) announced plans to consolidate it Eastern and Western Fleets into a single command in order to simplify command and control. The establishment of a Naval Patrol Command Centre (Puskodal) at Batam and Belawan with special forces were equipped to respond to armed attack from pirates and terrorists. It also launched Operation 'Gurita' which resulted in the arrest of several pirate gangs and seizure of six boats in the latter half of $2005 .^{7}$ As far as Philippines and Thailand is concerned, in 2003 the Philippine Navy created a fifth regional force in eastern Mindanao creating three commandos in areas troubled by Islamic insurgencies. The Royal Thai Navy (RTN) with strength of 12,000 personnel is taking all necessary steps to upgrade its maintenance and support capability through the acquisition of large aircraft and replenishment ships. A major addition to the RTN Fleet is the 11,400 tonne displacement - vertical/short-off landing carrier, the Chakier Naruebet, which is the first air-capable vessel to enter services in Southeast Asia.

Suggestions have also been made to secure ships through the Secure-Ship and Ship Loc system. While Secure-Ship is a non-lethal electrifying fence $(9,000+$ volts $)$ surrounding the whole ship, ShipLoc is fully complaint with the IMO regulation SOLAS XI-2/6 adopted during the diplomatic conference in December 2002. It's an inexpensive satellite tracking system which allows ships over 500 GT in case of danger, to activate an alarm button and automatically send a message to the ship owner or a competent authority. ${ }^{8}$

Where unilateral measures to curb maritime atrocities have more hurdles to cross, the bilateral and multilateral measures of the Southeast Asian littorals to arrest maritime terrorism are truly commendable. Here, of special mention is the role played by ASEAN - and other extra-regional powers including India. The subsequent section attempts to examine the above hypothesis.

\section{Bilateral \& Multilateral Cooperation}

While each nation of maritime Southeast Asia has been busy strengthening their naval forces, the three littorals straddling the Malacca Straits-Indonesia, Malaysia and Singapore felt the need to coordinate efforts to ensure the maritime security of the region. Thus efforts came in the form of coordinated patrols between Singapore and Indonesia in and around the Malacca Straits, the Surface Picture Surveillance System (SUPRIC) in May 2005 to provide real time surveillance of the Singapore Strait. Malaysia and Philippines signed a Memorandum of Understanding (MoU) allowing both the countries to conduct coordinated anti-piracy patrol along their common sea borders and exchange of information gathered from these patrols. So far, the most notable coordinated patrol by the littoral states has been the MALSINDO Corpat launched on 19 July 2004 by Indonesia, Malaysia and Singapore. MALSINDO is a year round and round-the clock coordinated patrol conducted by 17 ships of the three countries straddling the Straits. A hotline links the three naval command centres in Batam, Lumut and Changi. The successful implementation of MALSINDO reduced the incidents of piracy by the fourth quarter of 2004 with only 11 incidents reported in 2006 against 12 incidents in 2005 and 
37 incidents in 2004. This was followed by a 21 action plan proposed by the Institute of Defence and Strategic Studies for enhancing maritime safety and security in the Malacca and Singapore Straits. It builds on the significant measures undertaken at the Shangri-La Dialogue held in Singapore in June 2005; the Batam Joint Statement of the $4^{\text {th }}$ Tripartite Ministerial Meeting of the littoral states on the Malacca Straits and Singapore held in August 2005; followed by the Jakarta Statement on 7-8 September 2005. The Jakarta Statement acknowledged the rights and obligations under Article 43 of the 1982 UN Convention on the Law of the Sea with special emphasis on burden sharing. It invited, "the IMO to consider in consultation with the littoral states a series of follow on meetings to identify and prioritize the needs of the littoral states and for user states to identify possible assistance to respond to those needs, including information-exchange, capacity - building, training and technical support." This was followed on 13-14 March 2007 by a Consensus Document on Symposium on the Enhancement of Safety of Navigation and the Environmental Protection of the Straits of Malacca and Singapore in Kuala Lumpur. The Document acknowledged the commendable work undertaken by the Nippon Foundation for the safe passage of ships through the Straits and endorsed the significance of burden sharing and the establishment of a Malacca Straits fund. This fund would help shipping

- companies to voluntarily provide financial support for safe shipping and environmental protection of the Straits. ${ }^{9}$

\section{ASEAN's Role in Maritime Security}

This 42 year old regional organization has adopted a Charter in December 2007 and fully - committed itself to evolve into a security, economic and socio-cultural community and a common market by 2015. Often criticized as a 'nascent' security community based on the 'ASEAN Way' of abiding to the principles of non-interference in each other's internal affairs, pacific settlement of disputes and respect for one another's territorial integrity as underpinned in the Treaty of Amity and Cooperation (TAC) signed in 1971, ASEAN's diplomatic coherence and convergent purposes have been severely weakened by the economic crisis of 1997, East Timor's disintegration from Indonesia, the 'haze' problem and in dealing with various non-traditional security issues that gripped the region in the post Cold War period. Even last year ASEAN has been accused of doing little to address bilateral conflicts - between Thailand and Cambodia over an ancient Buddhist temple located near their boundary; Indonesia and Malaysia's dispute on the Ambalat Sea off Sulawesi over the question of rights to oil and natural gas; ASEAN's inability to influence or shape the course of events in Myanmar where pro-democracy forces have been put down by the military and Aung San Suu Kyi has been kept under house arrest for years. All these have brought ASEAN's reliance on 'consultation and consensus' under the scanner as scholars have pointed out that if sovereignty or non-interference in internal affairs is going to be upheld in bilateral disputes, then how ASEAN can aspire to become a security community? Hasn't ASEAN reached a stage after 42 years where it could dare to go beyond the norms of respect for absolute sovereignty and noninterference? ${ }^{10}$ 
But the very fact that the organization has succeeded to keep the region free of any major inter/intra-state military conflicts, while it has involved major countries around the world as dialogue partners through the ASEAN Summits, ARF, ASEAN+3 and East Asia Summit, proves that 'ASEAN in the driver's seat has been reasonably skilled and steady." ASEAN in July 1998 decided to practice "flexible engagement" among its member states on non state-centric threats. At the third ASEAN Informal Summit in Manila on 28 November 1999, ASEAN accepted Thailand's proposal to establish "the ASEAN troika" as an ad hoc body at the ministerial level so that "ASEAN could address and cooperate on issues affecting regional peace and stability. ${ }^{11}$

In the maritime arena, to address the problem of sea piracy and terrorism, by May 2002, ASEAN adopted a Work Plan by Special ASEAN Ministerial Meeting on Terrorism in - Kuala Lumpur. Among its commitments included calls for:

a) Establishing a compilation of national laws and regulation of ASEAN member countries pertaining to piracy and armed robbery at sea, enabling a regional repository of such laws and regulations to be made available on the ASEAN WEB.

- b) Increased information exchange and enhanced cooperation with the IMO, the International Maritime Bureau (IMB), the Federation of ASEAN Ship Owners Association (FASA) and ASEANPOL.

c) Enhance coordinated anti-piracy patrols;

d) Enhance and seek training programmes with ASEAN and other dialogue partners to equip maritime, custom police, port authority and other relevant officials for the prevention and suppression of maritime crimes.

On 12-15 May 2005, ASEAN hosted the International Maritime Defence Exhibition (IMDEX Asia: 2005) held in Singapore. India, Australia and Japan besides Singapore were among the regional powers who participated in the naval exercises, deploying some of their state-of-the art warship at the exhibition. ${ }^{12}$ On 19 June 2003 the ASEAN Regional Forum (ARF) issued a Statement on Cooperation against Piracy and Other Threats to Maritime Security. It recognized that piracy and armed robbery against ships and the potential for terrorist attack on vulnerable sea-lanes threatens the Asia-Pacific region and that regional cooperation efforts are necessary to combat transnational organized crime. It also endorsed ongoing efforts to establish a legal framework for regional cooperation to combat sea piracy and to consider proposals to have prescribed traffic lanes for larger ship tankers with coastguards or naval escorts wherever possible on the high seas. ${ }^{13}$

Even in tackling the issue of the South China Sea, ASEAN exercised its external institutional balancing strategy-first, through the official communiqué passed in July 1992. The declaration urged the settlement of all sovereignty and jurisdictional claim without resorting to force. Later, the 2002 Declaration of the Code of Conduct on the South China Sea urged all the parties to abide by the principle of the UN Charter, the 
1982 UN Convention on the Law of the Sea (UNCLOS), the Treaty of Amity and Cooperation (1971) and the Five Principles of Peaceful Coexistence. ${ }^{14}$ As a goodwill gesture China immediately moved to strengthen its ties with ASEAN and signed the TAC on 8 October, 2003 at Phnom Penh, Cambodia.

China has often followed a dual approach in dealing with ASEAN. On the one hand under its New Security Concept it follows friendly and cooperative relation with most of the Southeast Asian nations. On the other hand, it does not let outstanding issues be forgotten. Its disputed claim over most of the islands of the South China Sea and its naval installations at Pescardores (Pengshu), Pratas (Donghsa), Paracels (Xisha), Spratly's; its 'Myanmar policy' of building the regimes infrastructure and fulfilling its need for small - arms supply - primarily aimed to get an easy route from Yunan to the Indian Ocean has created much hiccups among the regional countries. ${ }^{15}$

In response ASEAN has been quick to pursue "soft balancing" by extending the involvement of Japan, India and Australia \{with US as an observer nation as a thinly disguised way to reduce China's influence in the region, on the one hand, while enabling - "constructive engagement" through ASEAN's shift in emphasis to ASEAN+3 (with China, Japan and South Korea), PRC's prominent role in the December 2005 East Asian Summit and the China-ASEAN Free Trade Agreement (FTA) which is the first of its kind the association has established, signaling China's centrality to Southeast Asia's economic growth (In 2007, ASEAN-China trade totaled \$171.1 billion, with Australia and New Zealand \$47.8 billion and with India \$37billion). Chinese energy investments in Indonesia rival those of Western companies. China's military sales are increasing to - Thailand, Malaysia and Indonesia - a new linkage that could lead to closer military-to military ties with the PLA. According to Sheldon Simon China's varied initiatives in Southeast Asia could be seen as new steps in a zero-sum competition with the USA. ${ }^{16}$

1

- There's no doubt that China's relation with Southeast Asia have been and will continue to

be marked by a mix of competition and collaboration. China's rising power remains a big concern for ASEAN as it seeks avenues to deal with security challenges from China through a mix of deterrence and cooperative security approach - its highest level of formal institutional cooperation well apparent in the case of the South China Sea Declaration of 2002. China had to succumb to ASEAN multilateralism on a subject that it had previously insisted on resolving on a bilateral basis.

In fact, ASEAN in addressing other outstanding maritime issues (non-traditional and nonstate centric issues) have sowed the seeds of Karl Deutsch's notion of an Asian "we-ness" highlighting all the traits of a 'matured' maritime community. ${ }^{1718}$ ASEAN through the Work Plans, maritime exhibition and Statement on Cooperation against Sea Piracy and other threats to maritime security, involvement of extra-regional powers to jointly patrol the SLOCs have tactically desuritised post Cold War maritime atrocities from the state level to the security-level. This has minimized the institutional dilemma between ASEAN and non-state centric issues. If this trend followed in addressing other nontraditional security issues, this can easily enable ASEAN's ascendancy from a 'nascent' 
to a matured' security community in the years to come. ${ }^{19}$ A closer look at the role played by USA, Japan and India will further help us to understand the all comprehensive maritime balancing act carried by ASEAN at the regional, sub-regional and extraregional level.

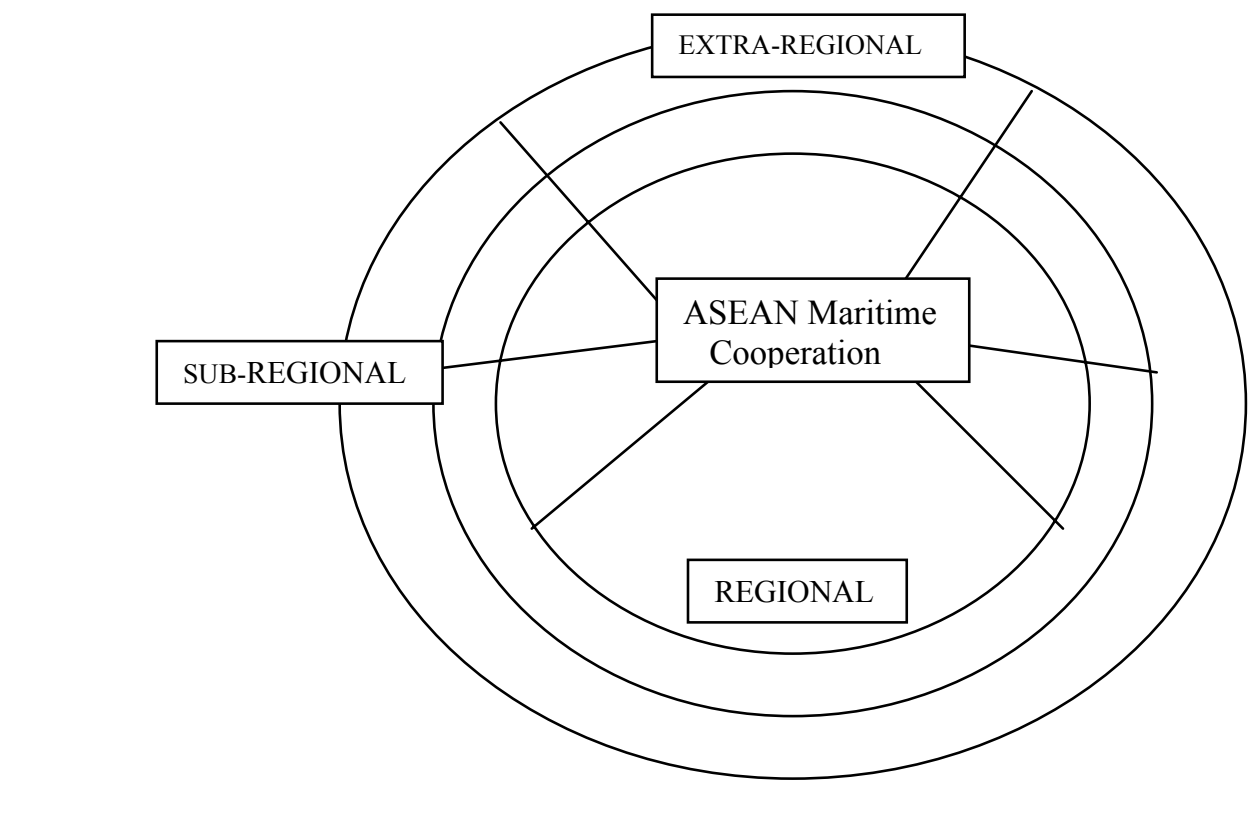

Role of US, Japan and India to combat Sea piracy \& Maritime Terrorism

Post 11 September 2001, US initiatives undertaken to ensure the security of the Malacca

- Straits include the Container Security Initiative (CSI), the Proliferation Security Initiative (PSI) and the Regional Maritime Security Initiative (RMSI). The 2006 US Quadrennial Defence Review (QDR) emphasizes plans to deploy stealthy B-1 and B-2 bombers to Guam and to move an additional carrier battle group totaling to six throughout the Pacific and Indian Ocean, along with 60 per cent of the US submarine force. ${ }^{20}$ It has also come up with a concept of a ' 1,000 ship Navy'. According to experts "the fleet is a global maritime partnership that unites maritime forces, port operators, commercial shippers and international, government and nongovernmental agencies to address mutual concerns. The United States Pacific Command (headquartered in Hawaii) has an area of responsibility (AOR) which stretches from the west coast of the US to the east coast of Africa. There are about 40 countries in the AOR; the US has formal treaties with six countries- Japan, South Korea, Australia, New Zealand, Thailand and the Philippines. 
For the Obama administration Southeast Asia remains the central front against terrorism in the Pacific (US Secretary of State Hillary Clinton's visit to Indonesia proves US renewed interest and commitment to the region). ${ }^{21}$

Although former President Bush's preoccupation with Iraq/Middle East had distanced USA from this zone, enabling an ambitious China to fill the 'big-power' vacuum. But ASEAN through institutional adaptability have aptly 'mediated' the impacts of a new regional order set by Beijing. Here, the ARF accommodated "the more benign aspects of world order while keeping its more interventionist aspects at bay" by "tying the US presence to the region but trying to dilute US influence through diffuse and highly consensual mechanism." 22 (US has been scrapped from major Asian arrangements- ASEM, East Asia Summit, Chiang Mia Initiative, Shanghai Cooperation Organisation). This institutional balancing strategy has helped smaller countries to integrate and accommodate an irredentist China and limit US unilateralism.

For USA, Japan has been the indispensable ally and counter-balance to China in East Asia. ASEAN has welcomed this alliance, initially as a reassurance that Japan would not - become an independent military force as it was during the Pacific War and more recently Tokyo is being seen as a significant contributor to sea lane security.

After 9/11, the Japanese Coast Guard became a fourth branch of Japan's armed forces. This is significant for Southeast Asia because it coincided with Tokyo's expanded antiterrorism legislation that authorized the dispatch of navy ships to the Indian Ocean to fuel American and British vessels bound for Afghanistan. By 2006, the Japanese Coast Guard - along with the Navy has been actively involved in securing the safety of the sea-lanes as Japanese merchant ships and freighters have also been subject to piracy in the Asian waters. (the Alondra Rainbow incident in 1999, when a Japanese cargo ship was hijacked off the Indonesian waters which was later retrieved by the Indian Navy. In 2001, another ship Selayang was rescued as a result of joint operation by the Malaysian and Indonesian navies). Tokyo convened several international conferences--- the 'International Conference of All Maritime Related Concerns, both governmental and private enterprises on Combating Piracy and Armed Robbery Against Ships,' from 28-30 March 2000. From 27-29 April 2000, it held the "Asia Anti-Piracy Challenges 2000: Regional Conference on Combating Piracy and Armed Robbery Against Ships," which consisted of heads of Coast Guard Agencies of 15 countries ranging from India to Japan. ${ }^{23}$ In September 2003, 16 nations met in Tokyo to finalise a draft $n$ anti-piracy pact. In February 2004, the JCG vessel Ryukyu was dispatched to participate in anti-piracy exercises with Thailand and the Philippines. The JCG has been instrumental in pushing forward the Asia Maritime Security Initiative, AMARSECTIVE 2004, adopted at the Head of Asian Coast Guard Agencies meeting in Tokyo, primarily aimed at tackling the problem of piracy, maritime terrorism and unlawful acts at sea with an intention to ensure maritime security and uninterrupted flow of seaborne trade. ${ }^{24}$ However, so far Japan's most successful contribution has been in the form of the Regional Cooperation Agreement on Combating Piracy and Armed Robbery against Ships in Asia (ReCAAP), the first government-to government agreement to enhance the security of regional waters. Its initiative aims to 
enhance multilateral cooperation among 16 regional countries, namely the ASEAN plus Japan, China, the Republic of Korea, India, Sri Lanka and Bangladesh to combat sea piracy and armed robbery against ships in the region. It includes an authoritative definition of "armed robbery against ships" and provides for the establishment of an Information Sharing Centre to be located in Singapore. ${ }^{25}$

Japan's maritime cooperation shows that although Tokyo is a close ally of the US, it is keen to play an independent role in the Asia-Pacific. This has been culminated by,

a) the recent and sustainable rise of China. This has strengthened Japan's desire to be a dominant power. Some experts have predicted an intense competition, including confrontation and possible conflict in future Sino-Japanese relations. They tend to see initiatives, like Prime Minister Junichiro Koizumi's January 2002 visit to Southeast Asia as reflecting strong Sino-Japanese friction and rivalry. A range of bilateral and multilateral issues, in fact, have widened the gap between the two countries. China bitterly opposed Japanese initiatives to support US efforts to give Taiwan some form of representation in the World Health Organization in 2004, while Tokyo supported US resolution regarding China's human rights practices at the annual UN Human Rights Commission meeting in April 2004. Chinese officials have continued to oppose Japan gaining a permanent seat in the expanded UN Security Council.

b) Japan-ASEAN relations which has seen an upswing, notwithstanding Southeast Asia's memories of the Japanese Imperial Army's brutality during World War II. Japan's role in boosting up the region's economy post 1997 (Japan contributed about $\$ 80$ billion towards resolving the Asian financial crisis), deployment of its navy in multilateral anti-piracy exercises in the South China Sea, its involvement through ASEAN +3, signing of the Treaty of Amity and Cooperation, simply proves that Japan is not prepared to lose out the position it has earned for itself in the region over the last two decades.

]c) The convergence of Indo- Japan relationship. This convergence of interest has been the driving factor behind their excellent chemistry of bilateral relationship despite the fact that bilateral trade between the two was less than one-third of the total volume of Sino-Indian trade during the financial year of 2007-08. The growing Indo-Japan relationship is not confined in any particular arena but covers all relevant fields. It was reflected during Indian Prime Minister Manmohan Singh's October-November 2008 visit to Tokyo.'26 This process adequately serves ASEAN's 'chess-board' diplomacy - to use the Japan-US, Indo-Japan and Indo-US amity to contain China on one hand, while allow ASEAN's institutional realism to check the hegemonic inklings of any of these powers to dominate the region on the other hand.

India's relationship with Southeast Asia has just started to deepen in the last several years as it has adopted it "Look East" policy spurred both by an attraction to East Asia's economic growth and by a desire to escape the constraints of South Asia. Gradually New Delhi has seen itself ascending from the sectoral dialogue partner status (1992) to a full 
dialogue partner of ASEAN in 1995 and a summit level partner in 2002. This was complemented by New Delhi's participation in ASEAN+10 meetings, the ASEAN+1 meeting as well as other senior-official meetings. In July 1996, she was made a member of ARF. This was followed in 1997 by BIMSTEC, the Mekong-Ganga Cooperation of 2000 and India's membership in the East Asia Summit (EAS) process which began in 2005. Delhi is also investing in Myanmar's oil and gas fields spending nearly $\$ 100$ million to develop the port of Switte.

In the maritime arena India's close proximity to Southeast Asian islands and its increasing reliance on the Indian Ocean for the transit of energy and commercial goods has called for deeper naval presence in this region. To avert any untoward incident across - these busy sea-lanes, the Indian Coastguard operates in anti-poaching, anti-piracy and anti-smuggling operations such as Operation Leech, Operation Golden Duck and Operation Hibicus. In 1998, the Coastguard intercepted the MV Alondra Rainbow- a Panama registered vessel belonging to Japanese owners that was hijacked by pirates off the Malacca Straits.

- At the bilateral level, the Indian Navy (IN) has been conducting joint naval exercises with the Singapore Navy since 1998. The IN and the Republic of Singapore Navy (RSN) conducted a bilateral exercise SIMBEX 05 from 24 February to 3 March 2005. With Indonesia, India has the 'IndoIndon' bilateral agreement that involves joint patrolling of the western flank of the Malacca Straits. In September 2004 the Indian Navy conducted IndIndoCorpat- with the Indonesian Navy.

- The Indian Navy has also been hosting the Milan exercises since 1995 to foster closer ties with the navies of the Southeast Asian countries. Milan 2003 which was conducted after the Bali bombings of 2002 brought in the issue of maritime terrorism within the maritime

domain. ${ }^{27}$

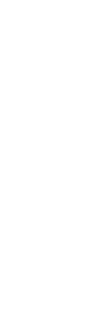

Following India's commendable role across the Indian Ocean Region the US expressed its willingness to grant India the epithet of a 'naval watchdog' of the region. In April 2002, the Indian and US naval ship undertook joint escort duties in the Malacca Straits. Sharde, assumed responsibility from the USS Cowpen to escort American commercial vessels carrying high-value goods transiting through the Straits; the US naval vessels patrolled sea areas in Southeast Asia while the Indian Navy concentrated on the Bay of Bengal and the Indian Ocean. The initiative emerged as an outcome of the understanding between New Delhi and Washington to revive the Malabar series of joint naval exercises suspended since India's 1998 nuclear tests. The Malabar series conducted three exercises in 1992, 1995 and 1996. Malabar-2005 was in fact a ten day joint naval coast exercise in the Arabian Sea with both sides involving their aircraft carriers, USS Nimitz and INS Viraat for the first time. India also tried to embolden its military relationship with USA through the CSI, PSI and RMSI process. India did not formally join the CSI till 2005 but it has approved CSI for the Nhava Sheva ports. ${ }^{28}$ With respect to PSI, the then foreign minister Yashwant Sinha at a Press Conference with US Secretary of state, Madeline 
Albright said: "We will discuss PSI at the official level and see how India can engage in the full process.'

While some scholars would make us believe that US competition in the Asia-Pacific region is actually China-centric with New Delhi being used as a 'buck' to keep an eye an irredentist China, it would be good to propose an Asia-centric theatre where a Chinese pole with its ties to Pakistan, Iran, Myanmar and an Indian pole with its ties to the core ASEAN members, Japan and smaller Pacific countries will chalk the future activities of the entire IO region with USA playing the role of an 'observer nation' (as it recedes to a new-isolationist facade) in this zone.

\section{CONCLUSION}

Albeit the power game, there is hardly any dispute that the Eastern Indian Ocean like its historical past is once again emerging into a 'cosmopolitan' maritime arena underpinned by long stretches of peaceful exchange of commodities, energy and other maritime - accessories. It would witness a new constellation of 'inward-looking' regional powers with a 'bazaar nexus' (for mercantile goods and energy supply) with Asian and nonAsian powers. Economically, small and middle powers of this region would share and accommodate all, (even adversarial postures) to draw the benefits of a highly globalised 'closely-knit' mercantile system. This 'economic goodwill' will spill-over to other comprehensive security domains-humanitarian assistance during natural calamities, addressing problems relating to AIDs, incurable diseases, environmental hazards, to name a few. Even problems relating to trade hazards - 'maritime mugging,' 'sea piracy,' 'illegal transfer of arms and ammunition, maritime terrorism, would call for a collaborative approach with no scope for any maritime balance of power or dominance of

any particular power (inside or outside). Here ASEAN would be the hub and leader of a
wider Asia-Pacific peace-keeper, calling for a durable peace, a nonhegemonic order

n (according to Amitav Acharya) ${ }^{29}$ in the maritime domain. The growing number of multilateral maritime efforts-MALSINDO Corpat, Eyes in the Sky, IMDEX-2005, AMARSECTIVE-04, Milan, PSI, RMSI, an ASEAN Workplane on Terrorism, installation of a Piracy Reporting Centre in Kuala Lumpur indicates the collective effort to address most nontraditional security threats.

Indeed the goodwill that has flown into the economic domain needs to percolate the cultural domain, which still lacks its frequency and luster of the glorious past- where two-way movement across borders were well evident in the historical relics, cultural activities (theatre, poetry), religiosity and scholarly exchange. Although loads have been talked about, there has been little in action. It will take quite sometime before the Indian Ocean can be truly termed as 'a hundred-horizon' an interregional arena. ${ }^{30}$

Of course, in the traditional maritime domain, the trend would be typically realistic with the two emerging giants - China and India competing and containing for maritime superiority. But this trend, although worrisome for other middle and small powers of the 
region would never escalate into a major conflict keeping in mind the 'trade benefits' that looms high over both India and China and the historical truth characterized by an Indian mandala system that was non-invasive in nature. The Indian kingdoms that emerged in 'Farther India' enjoyed only ties of tradition with Indian dynasties; there was no political dependence - and a Sinic tributary system that was merely aimed to influence politics and derive short-term economic advantage, but with no real control over people or land. ${ }^{31}$ And above all the presence of ASEAN that has enabled to keep any outstanding conflict situation at bay.

\section{Notes \& References}

-

${ }^{1}$ Mohan, Raman, "Maritime Threats and Security Issues," in V.R. Raghavan and Karl Fischer ed., Security Dimensions of India and Southeast Asia, TaTa McGraw-Hill, New Delhi 2005.

${ }^{2}$ Peter Chalk, "Low Intensity Conflict in Southeast Asia: Piracy, Drug Trafficking and Political Terrorism," Conflict Studies, Vol.305-06, 1998. Also see www.iccwbo.org/ccs/menu imb piracy. [A.O 20 July 2010].

${ }^{3}$ See jni.janes.com/archives-2000.htm [A.O 23 July 2010].

"Sam, Bateman, Catherine Zara Raymond and Joshua Ho, "Safety and Security in the Malacca and Singapore Straits," Policy Paper presented at the Institute of Defence and Strategic Studies, Singapore, May 2006.

- ${ }^{5}$ See www.cscap.org/documents/maritime\%20memo\%205.doc [A.O June 2010]

${ }^{6}$ See http://untreaty.un.org/ilc/text/convention/8_1__1958_ piracy.pdf [A.O July 2010].

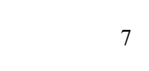

Sumathy Permal, "Malaysia, Indonesia and the Malacca Strait: Policy Similarities and Differences," Indian Ocean Survey, Vol.2, No.2, 2006. Also see Nick Brown, "Taking the fight to - " the pirates," Janes Navy International, May 2006.

${ }^{8}$ See www.imo.org [A.O July 2010].

${ }^{9}$ See, "The Batam Joint Statement of the $4^{\text {th }}$ Tripartite Ministerial Meeting of the Littoral states on the Straits of Malacca and Singapore Strait, Batam, Indonesia, 1-2 August 2005. http://app.mfa.gov.sg/internet/press/view-press.asp [A.O June 2010].

${ }^{10}$ Sudhir Devare, "ASEAN- Prospects and Problems- growth of trade and investment." Paper presented at the International seminar on "Culture, Society and Trade in Southeast Asia and India's Response, New Delhi, 3-4 March 2009.

${ }^{11}$ Kai He, "Does ASEAN Matter? International Relations Theories, Institutional Realism and ASEAN," Asian Security, Vol.2, No.3, 2006.

12 "Joint Communique of the Special ASEAN Ministerial Meeting on Terrorism," 20-21 May, 2001, Kuala Lumpur. www.aseansec.org/2002-asean-declaration.htm. [A.O July 2010]. 
${ }^{13}$ Mohamed Ali, "Maritime Security Cooperation the ARF Way," The Straits Times, 10 July 2003.

14 "Joint Declaration of ASEAN and China on Cooperation in the field of Non-Traditional Security Issues," $6^{\text {th }}$ ASEAN China Summit, Phnom Penh, 4 November 2002. www.aseansec.org/13186.htm [A.O June 2010]

15 Sheldon, W Simon, "Southeast Asian Security and its Influential Others," The Indonesian Quarterly, Vol.36, No. 3-4, 2008.

${ }^{96}$ Karl Deutsch ed., Political community and the North Atlantic area; international organization in the light of historical experience. Princeton: Princeton University Press, 1957.

${ }^{17}$ Concept taken from Kai He, op.cit, p.9.

${ }^{18}$ Sheldon Simon, op,cit, p.9.

${ }^{19} \mathrm{H}, \mathrm{B}$, Warimann, "US to Maintain Strong Presence in the Asia-Pacific," ADJ, December 2008.

${ }^{20}$ Michael Wesley, "Mediating the Global Order: The Past and Future of Asia-Pacific Regional Organisation," in David Lovell ed., Asia-Pacific Security: Policy Challenge, Singapore, ISEAS, 2003.

21 Japan Maritime Research Institute, Study on passage through the Straits of Malacca and Singapore, Tokyo, March 2001.

22 www.nippon-foundation-or,jp/eng/projects/index.htm [A.O July 2010].

$\left(\int{ }^{23}\right.$ www.recaap.org/publish/recaap/index.htm [A.O July 2010].

- 24 Sudhir Singh, "Japan and the Emerging New Asian Balance of Power," World Focus, January $20099^{32}$

— ${ }^{25}$ "Indian Navy," Annual Report 2007-08, Ministry of Defence, Govt of India. ${ }_{26}$ Ibid.

27 Amitav Acharya, "Nonhegemonic International Relations: A Preliminary Conceptualisation." Working paper presented at the Centre for Governance and International Affairs, University of Bristol, 2008.

${ }^{28}$ Sugata Bose, A Hundred Horizons: The Indian Ocean in the Age of Global Empire, Harvard University Press, Cambridge, London, 2006.

${ }^{29}$ Asad-ul-Iqbal Latif, "India and Southeast Asia: A view from Singapore.” Paper presented at the International Seminar on 'Culture, Society, Trade in Southeast Asia and India's Response, New Delhi, 3-4 March, 2009. 